\title{
AS CORES DA ESCURIDÃO: ASPECTOS IMPRESSIONISTAS NA ESCRITA DE ORÍGENES LESSA
}

\section{THE COLORS OF DARKNESS: IMPRESSIONIST ASPECTS IN ORÍGENES LESSA'S WRITING}

\author{
Mariângela Alonso ${ }^{1}$ \\ Guacira Marcondes Machado Leite ${ }^{2}$
}

Resumo: O objetivo deste artigo é trazer à luz aspectos impressionistas presentes na composição do conto "As cores", narrativa que faz parte da coletânea Balbino, homem do mar, de Orígenes Lessa (1903-1986). Procuramos, com esta análise, salientar o traço poético da obra de Orígenes Lessa, marcada por uma linguagem polissêmica e caracterizada muitas vezes pela permanência de traços impressionistas.

Palavras-chave: Impressionismo; linguagem poética; Orígenes Lessa.

Abstract: The aim of this paper is to bring to light impressionists aspects in the composition of the tale "The colors", narrative that is parto of the collection Balbino, seaman, by Orígenes Lessa (1903-1986). Sought with this analysis, note the trace of the poetic works of Orígenes Lessa, marked by a polysemic language and often characterized by the permanence of impressionists traces.

Key-works: Impressionism; poetic language; Orígenes Lessa.

\section{Introdução: incursões pelo Impressionismo}

O Impressionismo foi um dos principais movimentos da arte ocidental da segunda metade do século XIX e talvez de toda a modernidade. Sua técnica originou-se a partir das experiências artísticas presentes na obra de pintores como Claude Monet, Camille Pissaro, Edgar Degas, Pierre-Auguste Renoir, Alfred Sisley e Frédéric Bazille, os quais consagraram-se como os seus verdadeiros expoentes. Além destes conhecidos nomes masculinos, houve também um grupo feminino de artistas, tais como Berthe Morisot, Mary Cassatt, Marie Bracquemond e Olga Boznańska.

Os impressionistas utilizavam em suas telas uma composição refinada, procurando captar a expressão direta da luz e das cores, contando, muitas vezes, com cenários ao ar livre, num acabamento perfeito. Para tanto, a ação pictórica era transmitida por meio das impressões pessoais dos artistas, com o objetivo de refleti-las nas telas. De acordo com Janice Anderson, "a forma pela qual expressavam diretamente suas experiências visuais e a coragem com que manipulavam a luz e o uso da cor permanecem como um desafio a todos os outros artistas das gerações que hão de vir" (ANDERSON, 1997, p. 06).

\footnotetext{
${ }^{1}$ Doutoranda em Estudos Literários pela UNESP-Fclar/CNPq. E-mail: malonso924@gmail.com

${ }^{2}$ Livre docente do Departamento de Letras Modernas/UNESP-Fclar. E-mail: guacira@fclar.unesp.br
} 
Os aspectos predominantes do Impressionismo relacionam-se à busca de uma técnica peculiar de pintura semelhante às evoluções na mudança de pensamento do homem como ser dotado ao mesmo tempo de razão e imaginação, tendência observada ao longo da história pictórica e literária. Para Arnold Hauser (1995), o Impressionismo representa uma das estéticas mais importantes da arte ocidental, tanto pelas mudanças que ocasionou em relação ao modo de se conceber a arte, como pelo caráter de universalidade empreendido: "Antes do Impressionismo, a arte reproduzia os objetos por meio de sinais. Agora, representa-os por meio dos seus componentes, por parte do material de que são feitos." (HAUSER, 1995, p. 1051).

Assim, em oposição à cópia do real tantas vezes praticada pela pintura anterior, o Impressionismo propicia ao espectador a procura por subjetividades latentes, envoltas sobretudo no registro da percepção do artista apresentada nas telas: "[...] impressão direta, vívida de um momento, que é frequentemente reproduzida naquilo que parece um pormenor ao acaso do evento total" (GRIMME, 2009, p. 9).

Neste âmbito, a natureza passa a ser um princípio de inspiração para os artistas, que agora privilegiam as sensações transformadas contemplativamente em objetos. No exercício articulado entre cor e transparência, os pintores levam em conta os efeitos da luz, remetendo à inspiração fora dos ateliês, na observação da natureza e suas perplexidades. As telas impressionistas captam os momentos singulares, manifestos muitas vezes na impressão pessoal do artista frente ao elemento observado. Tal como afirmara o pintor Eugène Boudin:

Tudo o que é pintado diretamente e no local tem uma força, um vigor e uma vivacidade de toque que jamais poderão ser obtidos no estúdio; três pinceladas da natureza valem mais do que dois dias de trabalho no estúdio, sobre o cavalete. (BOUDIN apud ANDERSON, 1997, p. 5)

Entre os principais temas das telas, estavam o mar, as paisagens e seus horizontes, bem como a beleza oriunda do céu, das nuvens, envolvidos pela presença da luz, elemento primordial do método:

$O$ que os impressionistas estavam tentando fazer com a tinta era reproduzir, o mais fielmente possível, a rica intensidade visual que o olho humano transmitia para a mente. Procuravam analisar a cor e o tom de um determinado objeto o mais exatamente possível e pintar o jogo de luz sobre a superfície dos objetos. (ANDERSON, 1997, p. 6).

As combinações geradas pela luz, tais como o seu movimento refletido em extensões como a neve e a água, no exercício de luz e cor, levaram a sensações e impressões perante a paisagem observada, transformando-se em manchas, cujas 
pinceladas, com formas coloridas e breves, insinuavam algo como a volubilidade e a inconstância da vida, conforme afirma Arnold Hauser:

Toda a técnica improvisada com o esboçar rápido e informe, a percepção fugaz e aparentemente descuidada do objeto e o brilhante caráter do acidental da execução não vem a exprimir, em última análise, senão esse sentido de uma realidade vibrátil, dinâmica, sempre em transformação, que começou com a reorientação da pintura pelo emprego da perspectiva. (HAUSER, 1995, p. 1050).

O aspecto híbrido presente em boa parte das produções da Modernidade tem levantado polêmica entre os estudiosos. Uma das questões mais salientadas é o fato de que os limites entre os gêneros são tênues e constantemente apagados. Desta forma, a literatura conta com o hibridismo das formas, cujos aspectos constituem-se pelo amálgama dos gêneros, tais como a narrativa poética, o poema em prosa e a narrativa memorialística. A mistura entre os gêneros tornou-se bastante enérgica e acabou por eliminar fronteiras. Assim, a presença do Impressionismo foi sentida muito além da pintura, uma vez que seus ideais e aspectos alastraram-se por outras estéticas, mostrando "[...] à sociedade burguesa da sua época uma nova e moderna forma de pintar e de ver" (GRIMME, 2009, p. 6).

No campo literário o Impressionismo contou com os escritores adeptos da chamada écriture artist e apareceu nas composições de Henry James, Marcel Proust, Anton Tchékcov, Jules e Edmond Goncourt, além de Joseph Conrad. Precedentemente, houve tendências impressionistas nas obras de Baudelaire, Daudet, Verlaine e Rimbaud. Enquanto fenômeno literário, Arnold Hauser sintetiza as diferenças da técnica impressionista em relação à naturalista:

O impressionismo é menos ilusionístico do que o naturalismo; em vez da ilusão, fornece elementos do tema, em vez de uma imagem do todo, as várias peças que compõem a experiência. Antes do impressionismo, a arte reproduzia objetos mediante sinais; agora, representa-os através de seus componentes, através de partes do material de que são compostos. (HAUSER, 1995, p.899).

Hauser observa um certo descompasso entre o Impressionismo pictórico e o literário, já que enquanto prevaleciam os ideais impressionistas nas telas, a Europa, por sua vez, experimentava na Literatura o chamado Naturalismo, acompanhado pelo Decadentismo e Esteticismo. Além disso, a própria arte do Simbolismo, começou a ganhar notoriedade por volta de 1890, evidenciando em suas bases muitos dos aspectos impressionistas, tais como a disposição dos efeitos óticos e acústicos ao lado da combinação dos diferentes dados dos sentidos. 
Na Literatura, a principal característica impressionista relaciona-se à presença de aspectos sinestésicos e metafóricos, tais como a sugestão de imagens e a impressão de atmosferas. A experiência de luz, ar e cor são percepções próprias da pintura e encontraram na Literatura um meio adequado para serem expressas. Trata-se, portanto, de uma expressão pautada pela sugestão dos objetos, bem como das sensações e subjetividades despertadas por eles. Assim, o Impressionismo procura atingir o momento essencial, trazidos à tona por meio do estado de alma, ou seja, a subjetividade do artista. Nestas obras, o apego à descrição sobrepõe-se à narração, procedimento justificado pela ação contemplativa ou poética, o que caracteriza o caráter eminentemente visual da composição.

No Brasil, o Impressionismo não chegou a engendrar uma escola literária, porém, sua técnica encarna a presença de uma espécie de corrente ou tendência na Literatura Brasileira.

A transformação ocorrida na Literatura Brasileira entre o fim do século XIX e começo do século $X X$ foi consequência da união do Simbolismo com o Naturalismo, originando a tendência impressionista, que, posteriormente, ecoaria na gênese do movimento modernista. A este respeito, aponta o crítico Xavier Placer:

Com o advento do século $X X$, ao passo que o Simbolismo entra em recesso e passa a influir subterraneamente. O Impressionismo - valor original temperado por aquelas influências - singulariza-se, dando uma arte característica, que era simultaneamente transição para o Modernismo. (PLACER, 1962, p. 13)

Podemos evocar a presença literária de Raul Pompéia (1863-1895) como sendo o primeiro expoente no Brasil do século XIX. Sua obra O Ateneu: crônica de saudades (1888) apresenta um narrador guiado pela atitude memorialista ao focalizar o passado de forma poética e intimista pela deformação do objeto. Além de Pompéia, Machado de Assis (1839-1908) é citado pela crítica em romances como Dom Casmurro (1899) e Esaú e Jacó (1904). No caso específico de Dom Casmurro, José Guilherme Merquior observa:

O lembrar de Bentinho é uma forma vivencial, personalizada, da contemplação intelectual e abstrata de Schopenhauer. Aí temos a significação profunda do retorno à voz do narrador, ao relato subjetivo: a voz de Dom Casmurro é regida pela consciência do tempo íntimo. (MERQUIOR, 1996, p. 246).

A obra de Lúcio Cardoso (1912-1968) também foi sinalizada pela crítica como porta voz de aspectos impressionistas no século XX, uma vez que o romance Crônica da casa assassinada (1959) apresenta a pluralidade de vozes narrativas confundidas como em 
uma tela impressionista, tornando ambíguo ao leitor o que realmente ocorreu na Chácara dos Meneses, espaço da narrativa.

Adelino Magalhães (1887- 1969) foi outro nome apontado pela crítica, especialmente na recuperação espaço-temporal fugidia de romances como Casos $e$ impressões (1916) e Visões, cenas e perfis (1918).

A escrita impressionista opera uma atmosfera poética, na qual seu projeto de escrita busca não a retratação do mundo, mas sua revelação. Tal qual o trabalho do poeta, o narrador impressionista está submerso na eterna busca pela natureza primeva das palavras e a pluralidade de seus significados por vezes já esquecidos. É o que encontramos no conto "As cores", de Orígenes Lessa (1903-1986). Nele, o leitor entra em contato com o drama de Maria Alice, personagem cega, que habita um mundo altamente referenciado pelas cores.

O conto selecionado será propício para as discussões aqui realizadas, no sentido de enfatizar a linguagem híbrida, marcada muitas vezes pelos aspectos impressionistas e poéticos da escrita de Orígenes Lessa.

Desta forma, somados todos esses elementos, o presente artigo tenta percorrer o conto "As cores", de Orígenes Lessa, observando as impressões pictóricas vivenciadas pela protagonista Maria Alice e as possíveis convergências entre pintura e literatura presentes na constituição de uma linguagem impressionista e poética.

\section{As cores da escuridão: marcas impressionistas na escrita de Orígenes Lessa}

O conto "As cores" pertence à coletânea intitulada Balbino, homem do mar, publicada por Orígenes Lessa em 1960.

Em sua maioria, os contos da referida coletânea são marcados por um constante trabalho artesanal com a palavra, no que diz respeito à vigilância e autocrítica do autor em relação à plena realização da linguagem.

A publicação de Balbino, homem do mar, revela a personalidade literária de Orígenes Lessa, delineada sobremaneira por sua escrita transgressora. A obra atrai o leitor pela problematização que pauta sua linguagem e pelo estranhamento causado pelos motivos presentes em seu texto.

Vozes representativas da crítica brasileira, tais como Cavalcanti Proença, chamaram a atenção para o impacto que Ihes causou a escrita de Orígenes Lessa, ao afirmar: "O que, desde logo, nele chama a atenção é a espontaneidade que consegue dar 
às frases curtas e ao diálogo, o desenho de um pormenor posto no lugar justo, para efeito de verossimilhança" (CAVALCANTI PROENÇA, 1973, p. 15).

A narrativa de "As cores" trata de Maria Alice, jovem cega, porém imersa num mundo de códigos eminentemente visuais: "[...] um mundo não seu, mundo em que a imagem e a cor pareciam a nota mais viva das outras vidas de ilimitados horizontes" (LESSA, 1973, p.46).

O mundo de Maria Alice vai se compondo por meio de cores e imagens, ao mesmo tempo em que é apresentado ao leitor como um universo limitado, porém, poético na captação do espetáculo de transição da escuridão ocasionada pela cegueira da personagem e suas indagações frente às cores:

Que seria a cor, detalhe que fugia aos seus dedos, escapava ao seu olfato conhecedor das almas e dos corpos, que o seu ouvido apurado não aprendia, e que era vermelho nas cerejas, nos morangos e em certas gelatinas, mas nada tinha em comum com o adocicado de outras frutas e se encontrava também nos vestidos, nos lábios (seriam os seus vermelhos também e convidariam ao beijo, como nos anúncios de rádio?), em certas cortinas, naquele cinzeiro áspero da mesinha do centro, em determinadas rosas (e havia brancas e amarelas), na pesada poltrona que ficava à direita e onde se afundava feliz para ouvir novelas? (LESSA, 1973, p. 47)

A passagem acima lança mão de imagens sinestésicas ao focalizar um universo sensível e poético composto pelas variações de cores entre vermelho, branco e amarelo, apreendidas através das impressões analogamente colocadas à dimensão dos objetos e a experiências que, de algum modo, possuíam um sentido para Maria Alice.

O conto percorre o império dos sentidos da personagem, uma vez que as cores são sinestesicamente relacionadas à sua intuição e aos seus sentidos mais apurados diante dos objetos. Assim, através da figura da sinestesia, ocorre o registro das impressões da protagonista. De acordo com Balzi:

Quando as palavras e suas combinações não são suficientes para descrever com exatidão certos momentos de uma imagem ou algumas nuanças de um sentimento, ele [o poeta] escolhe palavras que, mesmo não tendo relação lógica entre si, quando unidas podem gerar no inconsciente do leitor a sensação desejada. Assim como duas cores se unem na retina do espectador para formar uma terceira. (BALZI, 1992, p. $50)$.

Além das cores acima mencionadas, o azul também é inserido mais de uma vez no texto, fazendo parte das indagações da personagem:

Diziam que o céu era azul. Que seria o céu? Um lugar, com certeza. Tinha mil e uma idéias sobre o céu. Deus, anjos, glória divina, bem-aventurança, hinos e salmos. Hendel. Bach. Mas sabia haver um outro, material, sobre as pessoas e casas, feito de nuvens, que associava à idéia do veludo, 
mais própria do cinza, apesar de insistirem em que o céu era azul. (LESSA, 1973, p. 49-50)

É pertinente lembrarmos que o azul é a cor oriunda do inglês azur, palavra intraduzível que tomou parte no código simbolista, conforme observado por Anna Balakian (2000). Ao azul estão relacionados o céu e sua "impenetrabilidade misteriosa" (BALAKIAN, 2000, p. 65), empregada nos poemas de Stéphane Mallarmé (1842-1898).

Os estudos de Gaston Bachelard também reportam-se à imagens do azul, no que tangem ao céu, identificando-as com infinidade, imensidão. $O$ teórico discute a dificuldade da representação de tais imagens perto de outras como o fogo, a água e a terra: "A palavra azul designa, mas não mostra" (BACHELARD, 2001, o. 164). Evocando os poemas de Paul Éluard (1895-1952), para quem os valores de sonho e de representação são intercambiáveis, Bachelard reconhece:

Diante do céu azul, de um azul muito suave, descolorido, diante do céu purificado pelo devaneio eluardiano, teremos oportunidade de apreender, no estado nascente, na dinâmica prestigiosa do estado nascente, o sujeito e o objeto - juntos. Diante de um céu de onde estão banidos os objetos nascerá um sujeito imaginário de onde estão banidas as recordações. $\mathrm{O}$ distante e o imediato se entrelaçam. (BACHELARD, 2001, p. 170-171)

No que tange ao conto "As cores", é possível encontrarmos movimento análogo. Em seus devaneios, Maria Alice intui as imagens do céu azul, eliminando, pela imaginação, as distâncias das fronteiras de representação. Em sua captação pelos sentidos, qualquer distância é abolida, entrelaçando-se poeticamente à sugestão das cores. É assim que no final do conto, a família retorna do cinema, enchendo a casa com "passos e vozes" e com a pergunta: "- Tudo azul? — perguntou Ana Beatriz, entrando na sala.

— Tudo azul — respondeu Maria Alice" (LESSA, 1973, p. 50).

Como se vê, no conto "As cores", há um entremeio de diálogos, pensamentos e sensações de Maria Alice, os quais confundem-se com a mistura de cores e seus efeitos transitórios, evocando, para o leitor, toda a subjetividade da personagem. Neste ponto, faz-se necessário lembrarmos que os pintores impressionistas não tinham interesse pela "cor real" e objetiva dos objetos. Com o procedimento da mistura entre as cores básicas, estes artistas obtinham a representação da realidade envolta pelos instantes de luz, vertendo para as telas os pigmentos e as cores do espectro solar.

A linguagem do conto de Orígenes Lessa torna-se, portanto, espontânea e lírica em suas descrições, atuando como uma espécie de desdobramento da subjetividade de Maria Alice. Conforme nos indica o crítico Malcolm Silverman acerca da galeria de 
personagens de Orígenes Lessa: "Os símbolos despontam vividamente, em dimensões quase alegóricas; as personagens germinam e desenvolvem uma própria verossimilhança; e os temas fluem das personagens, mais do que o contrário" (SILVERMAN, 1981, p. 232, apud HOHLFELDT, 1988, p. 73).

A presença das cores será notável por todo o conto de Orígenes Lessa, fazendo referência, muitas vezes, à indicação de classe social intuída pela personagem, conforme discutido mais adiante. É pela cor que Maria Alice percebe o mundo e suas diferenças:

Ninguém conseguia entender como sabia ela indicar qual o sapato ou a bolsa que ia melhor com este ou aquele vestido. Quase sempre acertava. Assim como ninguém sabia que, com o tempo, Maria Alice fora identificando as cores com sentimentos e coisas. O branco era como barulho de água de torneira aberta. Cor-de-rosa se confundia com valsa. Verde, aprendera a identificá-lo com cheiro de árvore. Cinza, com maciez de veludo. Azul, com serenidade. Diziam que o céu era azul. Que seria o céu? Um lugar, com certeza. Tinha mil e uma idéias sobre o céu. (LESSA, 1973, p. 49)

A pintura impressionista, realizada fora dos ateliês, procurava observar a natureza e suas oscilações, no encalço de um momento único, baseado na impressão pessoal do artista diante da realidade observada: "As pinceladas rápidas e o abandono da pintura perfeita são metáforas deliberadas da brevidade do momento e da rapidez da vida cotidiana" (GRIMME, 2009, p. 10). Podemos observar movimento semelhante no conto de Orígenes Lessa. Nele, as cores não constituem meros vocábulos estabelecidos pelas diversas tonalidades encontradas na natureza e no cotidiano da personagem. Ao contrário, tais cores adquirem vida própria, tornando-se ativas no mundo de Maria Alice. E assim, num jogo entre cor e sugestão, o conto nos remete ao Impressionismo na medida em que capta a subjetividade da personagem e seus devaneios frente à realidade.

O narrador, tal como o pintor impressionista, nos apresenta Maria Alice em meio a uma tela manchada pelas rápidas pinceladas de cores e pontos de luz, tais como o branco similarmente colocado ao lado da água que escorre de uma torneira, ou ainda o verde presente no cheiro das árvores. É importante lembrarmos que a presença do branco e da luz que emana dele estava constantemente presente nas técnicas da pintura impressionista, tais como o jogo dos reflexos e suas modulações na água, prática considerada como um dos instrumentos fundamentais para os pintores desta estética: "Inseparável das preocupações criativas do Impressionismo é o tratamento da cor e da luz" (GRIMME, 2009, p. 10).

Este procedimento atua no conto de Orígenes Lessa como a imagem poética de um mundo transposto para as impressões de um quadro, figurando de modo mais 
propício para a apresentação da subjetividade da personagem e seu momento de contemplação interior:

Ver era saber que um quadro não constava apenas de uma superfície estranha, áspera e desigual, sem nenhum sentido para o seu mundo interior, por vezes bonita, ao seu tato, nas molduras, mas que para os outros figurava casas, ruas, objetos, frutas, peixes, panelas de cobre (tão gratas aos seus dedos), velhos mendigos, mulheres nuas e, em certos casos, mesmo para os outros, não dizia nada... (LESSA, 1973, p. 48)

Ao longo do conto, Maria Alice está imersa em sua interioridade, vagando pela casa e pelos objetos que a compõem. A espacialidade da narrativa determina a condição de cega da personagem, reduzindo-a à casa e à lembrança do Instituto: "O livro abandonado sobre a mesa, o pensamento de Maria Alice caminhava liberto. Recordava agora o largo tempo que passara no Instituto, onde a família julgara que Ihe seria mais fácil aprender a ler" (LESSA, 1973, p. 49).

As imagens transmitidas pelo discurso poético do narrador em torno da personagem Maria Alice remetem-nos às telas impressionistas da francesa Berthe Morisot (1841-1895). As telas de Morisot foram importantes para as inovações da pintura impressionista, tal como as obras de Renoir, Pissaro, Monet ou Sisley.

Em um mundo artístico dominado pelos homens, as obras de Berthe Morisot reproduziram a realidade através da cor e da luz, propiciando formas de expressão de grande lirismo poético. Suas telas apresentaram uma concepção artística serena, quase sempre relacionada a paisagens repletas de frescor, com traços ágeis. Neste contexto, a figura humana ocupa o ponto de referência central em suas telas, tais como as cenas da vida doméstica ocupada por mulheres e crianças de sua época.

Em "Psique" (1876), Morisot nos apresenta uma bela jovem olhando-se contemplativamente ao espelho. A cena, transbordada pela luz, restringe-se a um espaço doméstico, com a ação da jovem a abrir um fecho na parte posterior de seu corpete. Uma série de manchas e tintas ligam-se ao ambiente, com pinceladas bastante indefinidas, denunciando a técnica impressionista: "[...] o movimento do pincel na mão do pintor permanece visível como pincelada ou ponto de tinta - a espontaneidade torna-se a imagem de marca do processo de pintar" (GRIMME, 2009, p. 10). 


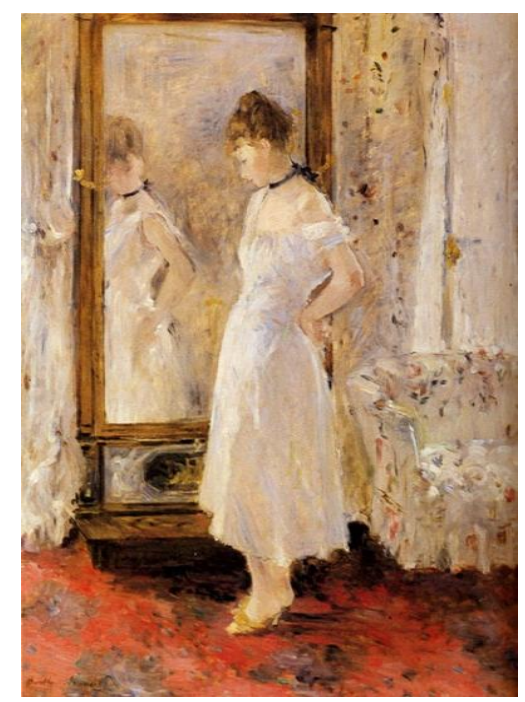

Berthe Morisot. Psique (1876). Oil on canvas. 65 X $54 \mathrm{~cm}$, Museo Thyssen-Bornemisza, Madrid.

Da forma como a imagem se apresenta, transpassada pelo reflexo da moça no espelho, tem-se uma espécie de metapintura, com um quadro inserido em outro quadro, semelhante às representações de bailarinas de Edgar Degas.

A tela, intitulada "Psique", refere-se, de imediato, ao conhecido mito de Amor e Psique, representado ao longo do imaginário dos séculos. Na mitologia, a jovem Psique era objeto de culto por sua rara beleza, sobrepondo-se à própria Vênus. A palavra "psique", de origem grega, pode significar tanto "alma" como "borboleta": "Esta alma, que sofre metamorfoses tal como a borboleta, era frequentemente representada como uma jovem com asas de borboleta" (GRIMME, 2009, p. 58). Na obra de Morisot, encontramos representação semelhante pela posição dos braços da moça diante do espelho. Todavia, na figura contemporânea de Morisot, as imagens transmitidas pelo discurso poético em que o intertexto está inserido não trazem qualquer rasto de Amor, o amante mítico. Porém, continua na tela a representação íntima da alma, com a figura feminina mergulhada em um mundo rico de sensibilidades. A individualidade é, portanto, a marca que a pintora encontra para a representação do objeto artístico perfeito:

Os impressionistas procuravam reproduzir tão direta quanto possível uma impressão que emanava do objeto. Ao colocar essa 'impressão' no centro da sua arte como uma sensação subjetiva, enfatizavam o aspecto da individualidade, o que é geralmente uma característica das sociedades modernas. (GRIMME, 2009, p. 10)

Da mesma forma, em "As cores", há o registro da subjetividade de Maria Alice. O conto de Orígenes Lessa apresenta a protagonista interagindo subjetivamente com 0 meio material e simbólico, mergulhada em seu próprio mundo de memórias e lembranças. A personagem toma para si a identidade dos objetos e dos gestos contemplados: 
Era o sentido que permitia encontrar o bonito, sem tocar, nos vestidos, nos corpos, nas feições, o bonito, variedade do belo e de outras palavras sempre ouvidas e empregadas e que bem compreendia, porque o podia sentir na voz e no caráter das pessoas, nas atitudes e nos gestos humanos, no Rêve d'Amour, que executava ao piano, e em muita coisa mais... (LESSA, 1973, p. 47-48)

Maria Alice está imersa em um presente alternativo que ela própria constrói e domina, por vezes muito mais satisfatório do que a realidade que se the apresenta e onde não consegue inserir-se:

- Ponha hoje o vestido verde, Ana Beatriz...

Dizia aquilo um pouco para não inspirar compaixão. Porque a piedade alheia a cada passo a torturava e Maria Alice tinha pudor de seu estado. Seria mais feliz se pudesse estar sempre sozinha como agora, movendose como sombra muda pela casa, certa de não provocar exclamações repentinas de pena, quando se contundia ou tropeçava nas idas e vindas do cotidiano labor. (LESSA, 1973, p. 48)

É nesta cisão entre a imaginação e a realidade, que a personagem de Orígenes Lessa busca um modo de sobrevivência dentro da sociedade, sentindo-se continuamente oprimida: "Mas como a remordia a admiração piedosa dos amigos... As palmas e os louvores vinham sempre cheios de pena [...]" (LESSA, 1973, p. 48).

A narrativa opera poeticamente com uma separação entre as esferas da realidade e da fantasia de Maria Alice, situando-a em um contraste entre o mundo interiormente idealizado e o espaço físico em que de fato se encontra: "- Machucou, meu bem? Doía mais a pergunta. Certa vez a testa sangrava, diante da família assustada e do remorso de Jorge, que deixara um móvel fora do lugar, mas teimava em dizer que não fora nada" (LESSA, 2009, p. 48).

Assim, por meio da sua poética percepção das cores, Maria Alice incorpora uma espécie de máscara que propicia o seu convívio no seio da família e da comunidade:

Claro que via muito pelos olhos dos outros. Sabia onde ficavam as coisas e seria capaz de descrevê-las nos menores detalhes. Conhecia-lhes até a cor... Se the pedissem o cinzeiro vermelho, iria buscá-lo sem receio. E sabia dizer, quando tocava em Ana Beatriz, se estava com o vestido bege ou com a blusa lilás. E de tal maneira a cor flutuava em seus lábios, nas palestras diárias, que para todos os familiares era como se a visse também. (LESSA, 1973, p. 48)

Ao criar uma ambientação altamente sinestésica com o recurso das cores, o conto de Orígenes Lessa abre-se para a possibilidade da reflexão em torno da existência humana, paulatinamente representada pelas impressões poéticas das descrições de lugares e objetos observados/sentidos por Maria Alice em sua escuridão. Por isso, a narrativa procura atingir o momento essencial, trazido à tona por meio do estado de alma, 
ou seja, a subjetividade da personagem: "Em seu pequeno mundo de volumes, de cheiros, de sons, todas aquelas palavras eram a perpétua renovação dos mistérios em cujo seio sua imaginação se perdia" (LESSA, 1973, p. 46).

O apego à descrição sobrepõe-se à narração, procedimento justificado pela ação contemplativa ou poética, o que caracteriza o caráter eminentemente visual da composição: "O conhecimento poético do mundo precede, como convém, o conhecimento racional dos objetos. $\mathrm{O}$ mundo é belo antes de ser verdadeiro. O mundo é admirado antes de ser verificado" (BACHELARD, 2001, p. 169).

A explosão de cores percebida interiormente na escuridão da protagonista propicia mais uma vez o diálogo com estética impressionista, uma vez que: "O motivo, quer seja um objeto isolado ou uma cena, esbate-se no fundo face à cor, à luz, e à execução da pintura" (GRIMME, 2009, p. 11).

A narrativa de "As cores" relaciona-se ainda ao mito de Tirésias, célebre adivinho tebano, filho de Cáriclo. Segundo uma das versões do mito, Tirésias tornou-se cego por castigo de Palas Atena; ele a teria visto, por acaso, banhando-se nua. A deusa, arrependida do castigo, deu a ele dons proféticos. Deste modo, o adivinho Tirésias, mesmo ignorando as aparências externas do mundo, participava de sua realidade mais secreta e profunda, negada aos mortais: "a cegueira, que às vezes é uma sanção divina, não deixa de relacionar-se com as provas iniciáticas" (CHEVALIER; GHEERBRANT, 1995, p. 217).

O mito atenta-nos para a ideia de compensação que acompanha a cegueira, permanecendo no imaginário popular. Assim, no conto de Orígenes Lessa, é conferido à Maria Alice a condição de ver interiormente, além da escuridão, como se a personagem possuísse o sentido da visão tão capaz quanto os demais familiares:

E como tinha os outros sentidos mais apurados, sempre se antecipava na descrição das pessoas e coisas. Sabia se era homem ou mulher o recémchegado, antes que se pusesse a falar. Pela maneira de pisar, por mil e uma sutilezas. Sem que Ihes dissessem, já sabia se era gordo ou magro, bonito ou feio. $E$ antes que qualquer outro, lia-lhe o caráter $e$ o temperamento. Àqueles pequeninos milagres de sua intuição e de sua capacidade de observar, todos estavam habituados em casa. (LESSA, 1973, p.49)

Fora da esfera do devaneio e da intuição, Maria Alice não poderia tomar consciência das representações contidas nas cores. Segundo Bachelard, "o ser, para tomar consciência de sua faculdade de representação, deve pois passar por esse estado de vidente puro" (BACHELARD, 2001, p. 169). Porém, as intuições e a poética presença das cores não conseguem saciar o cotidiano de Maria Alice, que, constantemente 
esbarrava-se nos estereótipos da cegueira, numa espécie de inadaptação ao mundo dos outros, como da vez em que estivera no Instituto: "E ali começara a odiar os dois mundos diferentes. O seu, de humildes e resignados, cônscios de sua inferioridade humana, o outro, o da piedade e da cor" (LESSA, 1973, p. 49).

Maria Alice refugia-se no passado e suas lembranças chegam até o Instituto, local em que passou a perceber mundos diferentes e também onde conhecera o "grande amigo" por quem se apaixonara:

Voltavam as longas horas em que falavam de Bach, de Beethoven, dos mistérios para eles tão claros da música eterna. Lembrava-se da ternura daquela voz, da beleza daquela voz. De como se adivinhavam entre dezenas de outros e suas mãos se encontravam. De como as palavras de amor tinham irrompido e suas bocas se encontrado... (LESSA, 1973, p. 50)

Toda esta aura de contemplação é quebrada quando a personagem lembra-se da chegada inusitada dos pais ao Instituto, impedindo-a de levar o namoro adiante: "Você não tem juízo, criatura? Casar-se com um mulato? Nunca! - Mulato era cor" (LESSA, 1973, p. 50).

A cena, ao focalizar o preconceito racial, revela para a protagonista a frustrada tentativa de realizar-se. Mais uma vez a cor atua como a fonte esclarecedora para Maria Alice, mostrando a ela uma espécie de segregação:

[...] o negro estava num cavalo que relinchava inquieto, com um sopro vigoroso de vida, e na suavidade e leveza de um vestido de baile, mas era ao mesmo tempo a cor do ódio e da negação, a marca inexplicável da inferioridade. (LESSA, 1973, p. 50)

Mesclando realidade e impressão, o conto "As cores" organiza-se pelo viés impressionista, delimitado pelo recorte apreendido por Maria Alice. O momento presente da personagem é retirado da continuidade em que vive para revisitar o passado. Para tanto, a memória torna-se imprescindível na produção impressionista. Nesta perspectiva, a cena reduz-se a pequenas situações, passando a ser episódica do universo das emoções da personagem. Conforme afirma Arnold Hauser:

A existência adquire verdadeira vida, movimento, cor, uma transparência ideal e um conteúdo espiritual à custa da perspectiva de um presente que é resultado o nosso passado. Não há outra felicidade senão a de recordar e do reviver, da ressurreição e conquistas do tempo que passou e se perdeu; porque, como diz Proust, os verdadeiros paraísos são os paraísos perdidos. (HAUSER,1995, p. 1112) 
Ao fazer uso de procedimentos impressionistas em sua narrativa, Orígenes Lessa institui um elo entre os elementos objetivos e subjetivos. A obra filtra as impressões de Maria Alice de modo que o mundo objetivo passe a ser visto com as lentes da alma.

\section{Conclusão:}

Este artigo procurou descrever e discutir a permanência de aspectos impressionistas no conto "As cores", de Orígenes Lessa. Não pretendemos, com este trabalho, reduzir a obra do autor como impressionista, haja vista a distância de temporalidade que a separa dos primeiros impressionistas. Mas procuramos, ao longo da análise, realizar um trabalho crítico de natureza dialógica, pautando-nos na permanência impressionista, sobretudo, no conto escolhido. Assim, a leitura crítica realizada poderá suscitar novas leituras, que com esta possam dialogar.

A construção do discurso foi analisada, de modo a revelar pontos comuns à técnica da pintura impressionista, na medida em que o autor projeta a interioridade da personagem Maria Alice em uma relação extremamente poética com as cores.

No caminho feito pelas páginas do conto "As cores", tivemos sempre em mente a preocupação de elucidar os aspectos poéticos da escrita de Orígenes Lessa. Para tanto, percorremos os pontos de convergência entre a obra e a técnica da pintura impressionista.

Ao escritor impressionista interessa sobremaneira os estados de alma de seus personagens, privilegiando a análise psicológica em detrimento da narrativa centrada em peripécias exteriores. O procedimento deste tipo de narrativa favorece não mais a descrição objetiva e realista das coisas tangíveis, porém a retratação das emoções originárias do espírito das personagens.

O modo de compreensão estático do mundo é contraposto à dinâmica do tempo. Neste contexto, os fenômenos estão em fluxo e a realidade torna-se um eterno devir. As mudanças ocorridas nas vidas dos indivíduos e das sociedades ganham destaque na prosa e na pintura impressionistas:

Esta tendência na arte do século XIX pressupõe que a impressão pessoal e subjetiva de um indivíduo não só merece ser descrita, como é reconhecida como a medida da vida na sociedade. $E$ assim se estabeleceram as fundações para a marcha triunfal do indivíduo no mundo moderno. (GRIMME, 2009, p. 14) 
A contingência é o elemento trazido para o conhecimento público pelos pintores impressionistas por meio da descontinuidade e fragmentação: "Já não era o realismo objetivo que estava no centro do seu empenho, mas sim a percepção totalmente subjetiva" (GRIMME, 2009, p. 18). Do mesmo modo como os artistas na pintura, os escritores representarão com a palavra as impressões experimentadas no tempo em movimento transfigurado e contínuo.

É neste sentido que se desenvolve o drama de Maria Alice, compondo-se ao mesmo tempo pela percepção do presente e pelo revisitar do passado. Suas lembranças e sentimentos são constantemente permeados pela presença das cores, num movimento contínuo de duração interior:

Estava longe aquele dia. Estava longe o Instituto, ao qual não saberia voltar, do qual nunca mais tivera notícia, e do qual somente restara o privilégio de caminhar sozinha pelo reino dos livros, tão parecido com a vida dos outros, tão cheio de cores... (LESSA, 1973, p. 50)

A técnica impressionista capta, portanto, os momentos fragmentados da consciência da personagem, caracterizados pela sua dinamicidade. Conforme afirma Arnold Hauser:

[...] a sensação de que cada fenômeno é uma constelação fugaz e jamais repetida, uma onda que desliza no rio do tempo, o rio em que 'não se pode entrar duas vezes', é a mais simples fórmula a que o impressionismo pode ser reduzida. Todo o método do impressionismo, com seus expedientes e ardis, inclina-se, sobretudo, a dar expressão a essa perspectiva heraclitiana e a sublinhar que a realidade não é um ser mas um devir, não uma condição mas um processo. (HAUSER, 1995, p. 897).

Assim, este devir, envolto pelo jogo de luz e sombra, tantas vezes realizado nas telas impressionistas, surpreende o leitor, que, agora, assiste a uma "pintura com palavras". Tal "pintura", ainda que não imite a realidade, consegue integrá-la em poesia, a partir do mundo das imagens, construídas com metáforas e sinestesias fecundas. $\mathrm{O}$ resultado é a harmonia entre o mundo da realidade e o da intuição, ambos reais, caracterizados pelo império dos sentidos e pelas emoções dos personagens.

\section{Referências:}

ANDERSON, Janice. A arte dos impressionistas. Tradução de Ruth Dutra. Rio de Janeiro: Ediouro, 1997. 
BACHELARD, Gaston. O céu azul. In: BACHELARD, Gaston. $O$ ar e os sonhos: ensaio sobre a imaginação do movimento. Tradução de Antonio de Pádua Danesi. 2. ed. São Paulo: Martins Fontes, 2001, p. 163-177.

BALAKIAN, Anna. O simbolismo. Tradução de José Bonifácio A. Caldas. São Paulo: Perspectiva, 2000.

BALZI, Juan José. O impressionismo. São Paulo: Ática, 1992.

CAVALCANTI PROENÇA, Manuel. Orígenes Lessa: artesanato e espontaneidade. In: LESSA, Orígenes. Balbino, homem do mar. 2. ed. Rio de Janeiro: José Olympio, 1973. p. 14-16.

CHEVALIER, Jean \& GHEERBRANT, Alain. Dicionário de símbolos. 9 ed. Rio de Janeiro: José Olympio, 1995.

GRIMME, Karin H. Impressionismo. Tradução de Maria do Rosário Boléo. Germany: Taschen, 2009.

HAUSER, Arnold. História social da arte e da literatura. Tradução de Álvaro Cabral. São Paulo: Martins Fontes, 1995.

LESSA, Orígenes. As cores. In: LESSA, Orígenes. Balbino, homem do Mar. 2.ed. Rio de Janeiro: José Olympio, 1973. p. 46-50.

MERQUIOR, José Guilherme. De Anchieta a Euclides: breve história da literatura brasileira. Rio de Janeiro: Topbooks, 1996.

PLACER, Xavier. Adelino Magalhães e o impressionismo na ficção. Rio de Janeiro: Livraria São José, 1962.

SILVERMAN, Malcolm. Moderna ficção brasileira. Rio de Janeiro: Civilização Brasileira, 1981, p. 232. v.2. In: HOHLFELDT, Antonio. Conto brasileiro contemporâneo. 2. ed. Porto Alegre: Mercado Aberto, 1988, p. 73. 
Revista InterteXto / ISSN: 1981-0601

v. 5 , n. 1 (2012)

Reprodução da tela "Psique", de Berthe Morisot feita a partir de:

GRIMME, Karin H. Impressionismo. Tradução de Maria do Rosário Boléo. Germany: Taschen, 2009. 